the General Post Office, for example, hopes to save $£ l l$ million in the coming year by running down its stocks of supplies and by postponing the renewal of various kinds of ancillary equipment-motor vehicles, for example. The postponement of various items of capital expenditure is, however, the most favoured expedientthe railways, for example, will put off the start of the electrification of the line between London and Glasgow for a year, while the British Airports Authority will postpone its scheme for a helicopter terminal for a similar period. The Central Electricity Generating Board will probably take the opportunity afforded by the Government's request to reduce expenditure by $\mathfrak{f 1 7}$ million to put off the scheme for building a power station at Seaton Carew in north-east England. In the past few months, there has been some dispute about the fuel to be used for this power station-coal, oil or nuclear power. Coal interests have been urging that it would be unscemly to burn anything but coal in a power station built on the edge of a coalfield, and there seemed at one time to be a possibility that the Prime Minister had given an undertaking that this point of view would not be overlooked. It would be understandable if the Central Electricity Generating Board welcomed the opportunity with which it has now been presented.

Research is likely to be more dircetly affected by the request for a reduction of expenditure of $£ 3$ million in the budget of the Atomic Energy Authority than by any of the other measures, larger though they may have been, which were announced by the Chancellor of the Exchequer. It seems to have been decided that the chief reactor projects will not be affected, which is entirely sensible. It is, however, significant that the Atomic Energy Authority now considers that the Dragon reactor is somewhere near the top of this list, along with the advanced gas-cooled reactor and the fast reactor. Evidently there are now high hopes that the technology of the Dragon will help enormously with future development of the advanced gas-cooled reactor. But if most rcactor projects are sacrosanct, it probably follows that the authority will have to look to its research establishments for economies. The trouble here is that most of what could be done to economize at Aldermaston would not count in the authority's favour because it is paid for out of the defence vote, while the fusion laboratory at Culham is already faced with the prospect of trimming its sails by 50 per cent over the next five years.

In the circumstances, it is perhaps inevitable that the main burden of the economies ahead will fall on the laboratory at Harwell. It may even be that the Chancellor of the Exchequer is hoping that the dilemma which he has created will persuade the Minister of Technology finally to decide what should be done about Harwell. His colleagues in the British Government-and certainly those outside who reckon to keep a wateh on developments like these-will be hoping that the necessarily stop-gap reductions of expenditure now announced will quickly be followed by policy decisions which promise a more permanent reduction of the scale of government expenditure.

\section{London Intelligences}

Tre Research and Intelligence Unit of the Greater London Council has now been in action for nearly a year, the director of the unit, Dr Bernard Benjamin, having been appointed in 1966. Two divisions of the unit-GLC Statistics, and Research, are well established and a third which will serve the London boroughs will begin work early in 1968 . The work of the unit, with particular reference to the field of information and intelligence, was described in a paper by $R$. $G$ Dunsmore and R. E. Fry at a recent meeting of the Institute of Information Scientists.

The Research and Intelligence Unit does not have complete responsibility for statistics and research in the GLC, for separate departments such as housing took them over between the setting up of the GLC in 1965 and the formation of the unit. The unit's job, among other things, is to co-ordinate such activities. Mr Fry quoted three other aspects of the original terms of reference of the unit that are particularly important, and discussed the actions taken by the unit in these directions. The purposes mentioned were the setting up of an information system, which would contain statistics for forecasting material trends, and the publishing of a regular series of London statistics.

With the wide range of activities of the GLC involving an annual budget of over $£ 400$ million, the unit had to decide what statistics would be most useful. The conclusion was reached that information is required to support the needs of strategic planning in the widest sense. The unit would be the only body within the GLC with a comprehensive view of information kept in the different departments, and because of this could advise on gaps, unnecessary overlaps, coding and classification. One working group that has been set up is seeking agreement between certain GLC departments and the London boroughs on standardization of units for statistical data on transport and land use.

As the clcrk to the council, in whose department the unit is located, has recently been up-ranked to directorgeneral, to be the GLC's principal adviser on policy, the unit will be in effect his co-ordinator.

\section{Schools Council and A-Level}

THE Schools Council has at last published the docu. ment which embodies its proposals for a new pattern for the sixth form curriculum (Some Further Proposals for Sixth Form Work, HMSO, 3s. 6d.). This document has already been circulated to universities and was indeed the subject of the discussion among representatives of the universities at a meeting of the Senate House of the University of London on November 17. The proposals have been circulated to universities by the Standing Conference on University Entrance. The first reaction of the universities at the meeting in November was one of hostility to the Schools Council's proposals, chiefly on the grounds that they do not cater adequately for the need for a broader curriculum in the sixth form. The matter is to be discussed more formally at another meeting in the new year, and the universities are hoping to give the Schools Council a formal reply at Easter or thereabouts. The chances are that the universitics will suggest, through the standing conference, an alternative to the sixth form pattern suggested by the Schools Council which takes the form of a broader pattern of studies (see Nature, November 25, 1967).

The essence of the new proposals by the Schools Council, which are said to have evolved from the 